\title{
Menelusuri Jejak-Jejak Kekerasan dalam Islam
}

\author{
Sembodo Ardi Widodo
}

Islam is merely claimed as "violence religion". It may be true or false, or even it is just a "mythology". But it must be understood that, in fact, in the history of Islam, some $k i n d s$ of violence have risen because of action of individual or group of Moslem by the name of Islamic religion. Beginning from scripturalism, from Qoran and Sunnah, the texts was understood and interpreted for the sake of action, created an aqidah and syari'ah, than created an attitude.and behavior of life of Moslem; and because of it's model of interpretation that faced to action and confronted with current condition and development of modern society in various aspects: political, social, cultural, and economical aspect, so militant Moslem groups rose against the unjustice actions, not only faced to another group with different religion but also to another Moslem group.

Kata kunci: sejarah, Islam, kekerasan, skriptual, dan jihad

$B$ erita tentang kerusuhan dan tindakan kekerasan ${ }^{1}$ di Indonesia hampir tidak pernah berhenti dari kesadaran publik. Ketika suatu tindakan kekerasan atau kerusuhan massa yang dilakukan oleh orang-orang atau kelompok tertentu terjadi dan kesadaran publik belum sepenuhnya hilang akan hal itu, tiba-tiba sudah terjadi lagi tindakan kekerasan yang lain. Media massa secara massif mengekspos peristiwa tersebut baik dalam. TV, surat kabar maupun majalah. Kekerasan akhirnya menjadi "budaya" tersendiri yang eksistensinyả tidak kalah populer dengan budaya-budaya lain, karena selalu diekspos oleh media massa.

1 Jamil Salmi membagi kekerasan menjadi empat jenis: kekerasan langsiung, kekerasan tidak langsung, kekerasan represif; dan kekerasan alienatif. Lihat, Jamil Salmi, Violence and Democratic Society: Hooliganisme dan Masyarakat Demokrasi, Terj. Slamet Raharjo, (Yogyakarta: Pilar Humania, 2005), p. 32-42. Dalam tulisan ini, yang penulis maksudkan dengan kekerasan adalah kekerasan jenis pertama, kekerasan langsung, yang merujuk pada tindakan penyerangan fisik atau psikologis seseorang secara langsung, seperti pembunuhan individual atau kelompok, tindakan paksa atau brutal yang menyebabkan penderitaan fisik atau psikologis seseorang dalam bentuk pengusiran paksa terhadap suatu' 
Tindakan kekerasan yang terjadi di Indonesia dilatarbelakangi oleh berbagai motif, dari motif politik, ekonomi, sampai motif agama. Belum lama ini kita menyaksikan kerusuhan yang diikuti oleh tindakan kekerasan dalam penyelenggaraan Pilkada di Tuban. Kerusuhan Tuban terjadi karena massa pendukung pasangan Noor Nahar Husaen-Go Tjong Ping yang kalah dalam pemilihan Bupati/wakil Bupati Tuban mengamuk. Massa merusak dan membakar pendapa dan Gedung KPU Tuban. Massa juga merusak rumah pribadi bupati incumbent, Haeny Relawati, termasuk perabotan yang ada di dalamnya. Tiga unit mobil yang ada di garasi rumah itu dirusak setelah dikeluarkan ke jalan. ${ }^{2}$

Peringatan Hari Buruh tanggal 1 Mei 2006 yang lalu juga masih sedikit diwarnai oleh tindakan dan aksi-aksi anarki yang dilakukan oleh para demonstran buruh, di lbu Kota atau di daerah seperti Lampung dan Surabaya. Empat bulan sebeiumnya di Poso, daerah bekas konflik antar umat beragama, terjadi kerusuhan dan tindakan kekerasan. Lima kantor di lingkungan pemda setempat terbakar. Peristiwa itu disusul meledaknya dua bom di dua lokasi dalam waktu yang berbeda. Ironisnya peristiwa itu berlangsung saat malam Idul Adha dan pengamanan telah ditingkatkan, juga setelah lima hari dibentuknya Komando Operasi Keamanan Sulteng pada 5 Januari 2006 . $^{3}$

Hari-hari akhir tahun 2005 yang lalu kita juga dihentakkan oleh ledakan bom di Palu, Sulawesi Tengah. Ledakan tersebut melukai kurang lebih 50 orang dan menewaskan 8 orang. Sebelum itu berbagai bom juga meledak di berbagai tempat, seperti di BEJ, Kedubes Australia, Hotel JW Marriot, dan Bom Bali I dan Bom Bali ll. ${ }^{4}$.

Dalam skala internasional, kita juga menyaksikan bagaimana sebuah negara adidaya sèpertí Amerika*Serikat dapat diserang oleh sekelompok teroris yang merobohkan gedung WTC 11 September 2001. Tragedi ini selanjutnya menguatkan popularitas gerakan Islam militan di satu sisi, dan di sisi lain menjadi "mitos" Islam sebagai sarang teroris.

Melihat sekilas tentang tindakantindakan kekerasan di atas, tampaknya motif agama menjadi variabel yang cukup kuat yang mendorong terjadinya kenusuhan massa dan tindakan kekerasan. Publik bisa saja menilai bahwa agama, secara tidak disadari, mengandung unsur kekerasan. Dan ketika para pelaku kekerasan itu banyak yang berasal dari pemeluk agama Islam, lebih-lebih lagi mantan santri pesanten, maka publik pun menilai bahwa agama Islam juga mengandung unsur kekerasan, atau setidaknya ajaran Islam itu memberikan peluang kepada pemeluknya untuk melakukan tindakan kekerasan atas nama agama. Benarkah Islam itu mengajarkan kekerasan, atau sebaliknya bahwa Islam itu justru anti-kekerasan. Diskursus di sekitar permasalahan inilah yang cukup menarikuntuk djelaskan lebih mendalam untuk memberikan gambaran yang proporsional tentang islam dan realitas budaya kekerasan yang

masyarakat, penculikan, penyiksaan; pemerkosaan dan penganiayaan, perampokan, atau tindakan-tindakan anarkis yang mengganggu hak-hak asasi manusia yang paling mendasar, yaitu hak untuk hidup.

2 Lihat, Harian Pagi BERNAS, Selasa, 2 Mei 2006, p. 1 dan 6.

${ }^{3}$ Lihat lebih lanjut, Jawa Pos, Rabu, 11 Januari 2006, p. 1.

${ }_{4}$ Untuk analisis Bom Palu khususnya, bisa dibaca lebih lanjut, Oksidelfa Yanto, "Bom Palu dan Masih Terancamnya Human Security, dalam Harian Seputar Indonesia, Kamis, 5 Januari 2006, p. 8. 
dilakukan oleh individu atau keiompok tertentu yang mengatasnamakan Islam.

\section{Kekerasan dalam Lintas Sejarah Islam}

Islam selalu disamakan dengan kekerasan. Nabi Muhammad telah digambarkan sebagai Rasulullah yang berdakwah dengan pedang oleh sejumlah penulis Barat. Pertentangan yang panjang dan sengit antara kaum Muslim dan Kristen dalam perang Salib Abad Pertengahan, menciptakan gambaran mengenai kaum Muslim sebagai orang yang haus darah. Ajaran Islam tentang jihad, suatu istilah yang kurang dipahami, juga menekankan penyamaan Isiam dengan kekerasan. Revolusi Islam Iran di 'mana kita menyaksikan penyiksaan diri sebagai bentuk penyesalan para mullah militan berjanggut panjang turun ke jalan dan pergolakan-pergolakan di Timur Tengah, semuanya mendorong lahimya mitos Islam sebagai agama kekerasan. ${ }^{5}$ Alasan utama mengapa Islam dapat digunakan untuk membenarkan kekerasan adalah karena Islam berorientasi pada aksi, yang mendesak penganutnya untuk bertindak melawan ketidakadilan. ${ }^{6}$

Tindakan kekerasan atas nama agama, paham atau aliran keagamaan, dapat dilacak jejaknya dalam sejarah Islam itu sendiri. Sejarah mencatat bahwa kaum Khawarij tergolong dalam kelompok yang berorientasi pada aksi kekerasan. Kaum Khawarij yang mula-mula berasal dari Arab Badui yang hidup di tengah padang pasir yang tandus mempunyai watak yang keras, pemberani, bersikap merdeka, tidak mau bergantung kepada kelompok lain, dan cara berpikimya sangat sederhana dan dangkal. ${ }^{7}$ Mereka juga mempunyai sifat fanatisme yang solid, karena itu mereka sangat teguh dalam memegangi pendapat dan ajaran yang mereka yakini. Mereka cepat menerima ajaran agama, dan apa yang mereka dapatkan diamalkan apa adanya. Di samping itu, mereka juga mudah tersinggung dan cepat marah, dan bila kemarahannya memuncak, mereka tidak segan-segan membunuh; selain itu mereka juga suka berperang. ${ }^{*}$

Kaum Khawarij dari sekte'al-Azariqah menganggap musyrik siapa saja yang tidak sepaham dengannya dan menyatakan perang terhadap mereka, bahkan mereka yang tidak mau hijrah ke perkampungan alAzariqah dipandang sebagai kafir yang halal darahnya. Tidak hanya orang tuanya yang boleh dibunuh, tetapi juga anak-anak di bawah umur pun mereka halalkan darahnya untuk dibunuh. ${ }^{9}$ Mereka mempunyai prinsip perkampungan, yaitu bahwa non Azariqah adalah zona perang (dar al-harb) yang wajib ditumpas habis sampai ke akar-akarnya.

${ }^{5}$ Seni Mudmarn, “Negara, Kekerasan dan Bahasa: Tinjauan atas Sejumlah Hasil Studi mengenai Kaum Muslim Muangthai" dalam Saiful Muzani, (Ed.), Pembangunan dan Kebangkitan Islam di Asia Tenggara, (Jakarta: LP3ES, 1993), p. 330-331.

- Chaiwat Satha-Anand dan Qader Muhaideen, "Bulan Sabit Anti-Kekerasan: Refleksi atas Perjuangan Kaum Muslim Muangthai" dalam Saiful Muzani, (Ed.), Pembangunan dan Kebangkitan..., p. 213.

7 Lihat, Harun Nasution, Teologi Islam, (Jakarta: UI Press, 1983), p. 13.

${ }^{8}$ Lihat, Ahmad Amin, Fajr al-Islam, (Kairo: Maktabah al-Nahdlah al-Mishriyah, 1975), p. 30-39.

- Prinsip dibolehkannya membunuh anak-anak didasarkan pada do'a Nabi Nuh yang terdapat dalam ayat 26-27 dari surah Nuh: "Ya Tuhanku jangan Engkau beri orang-orang kafir itu hidup di muka bumi ini sebab jika Engkau membiarkan mereka hidup niscaya akan menyesatkan hamba-hamba-Mu saja, dan mereka akan melahirkan orang-orang fasik dan kafir". Lihat lebih lanjut, Muhammad Husain al-Dzahabi, al-Tafsir dan al-Mufassirun, (Kairo: Dar al-Kutub al-Haditsah, 1962),;p. 309. 
Untuk itu, kalau ingin selamat mereka harus hijrah ke zona.Islam (dar al-Islam) yaitu perkampungan Azariqah itu sendiri. Demikianiah, dalam perjalanan sejarah, kaum Khawarij sering melakukan teror dan pembunuhan terhadap orang-orang yang dianggap tidak sepaham dengannya.

Selain golongan Khawarij, Aliran Mu'tazilah yang nota bene merupakan gerakan keagamaan Islam, yang tidak pernah membentuk pasukan, tidak pernah menghunus pedang, dan terkenal dengan corak pemikirannya yang rasional, namun ketika mereka mempunyai kekuatan, mereka tidak segan-segan menggunakan cara kekerasan dan tekanan-tekanan terhadap pihak-pihak yang tidak sepaham dengan paham mereka. Lebih-lebih setelah diakuinya aliran ini sebagai aliran resmi negara oleh khalifah al-Ma'mun pada tahun 827 M. dan dua khalifah penerusnya, alMu'tasim dan al-Wasiq, tindakan kekerasan yang mereka lakukan semakin menjadi-jadi karena didukung oleh negara. ${ }^{10}$

Kekerasan dan tekanan-tekanan yang dilancarkan oleh golongan Mu'tazilah 'tergambar dalam tindakan mereka yang memaksakan orang lain untuk menerima doktrin dari ajaran mereka tentang barunya al-Qur'an. Dalam hal ini, khalifah al-Ma'mun mengadakan pemeriksaan terhadap para qadli pada masa itu dan mereka dipaksa untuk mengaku di depan umum bahwa alQur'an itu makhluk. Peristiwa ini dalam. sejarah dinamakan dengan mihnah (inquisisi). Kebijakan mihnah itu tidak hanya berlaku bagi para qadli tetapi juga bagi para saksi yang akan bersaksi di pengadilan, sehingga akhirnya meluas kepada masyarakat umum. Dalam prakteknya, bagi mereka yang tidak mau mengakui bahwa al-Qur'an itu makhluk (baru) maka mereka dicambuk dan dianiaya. Salah satu ulama besar yang mengalami tindakan kekerasan ini adalah Imam Ahmad bin Hambal, pendiri salah satu mazhab Sunni, yang mana dia juga dimasukkan penjara. ${ }^{11}$

Kebijakan mihnah ini dilandasi dengan logika, yaitu bahwa pengakuan adanya sesuatu yang kekal selain Allah itu sendiri merupakan perbuatan syirik, dan syirik merupakan dosa besar yang tidak bisa diampuni. Cara berpikir ini bertentangan dengan pendapat ulama Sunni ketika itu, yang oleh Montgomery Watt dikatakan sebagai blok konstitusionalis, yang ajarannya banyak diikuti masyarakat Muslim pada waktu itu. ${ }^{12}$ Namun demikian, ketika khalifah al-Mutawakkil naik tahta dengan dukungan ahl al-hadits, kaum Mu'tazilahlah yang dikejar-kejar karena pendapat dan keyakinan mereka dianggap sesat. ${ }^{13}$

Khalifah al-Mutawakkil adalah seseorang yang tidak menyukai dan alergi terhadap pemikiran-pemikiran rasional yang dipakai oleh alitan Mu'tazilah, dan sebaliknya mendukung aliran Sunni serta menempatkannya sebagai teologi negara. Sebagai konsekuensi logisnya, ia membebaskan Imam Ahmad bin Hambal dari tahanan, lalu digangkat sebagai qadli. Ulama Sunni ditempatkan ke dalam kedudukan yang penting dan strategis untuk menggantikan pemuka-pemuka Mu'tazilah. p. 61.

${ }^{10}$ Lihat, Harun Nasution, Teologi islam,

1 Nurcholish Madjid, Islam, Doktrin dan Peradaban, (Jakarta: Yayasan Wakaf Paramadina, 1995), p. 208.

${ }^{12} \mathrm{~W}$. Montgomery Watt, Kejayaan Islam: Kajian Kritis dari Tokoh Orientalis, Terj. Hartono Hadi Kusumo, (Yogyakarta: Tiara Wacana, 1990), p. 6.

${ }_{13}$ Machasin, Fundamentalisme dan Terorisme, Makalah disampaikan dalam "Moslem Scholars Congress, Reading of The Religious Texts and The Roots of Fundarnentalism", di Hotel Saphir Yogyakarta, 13 Juni 2004, p. 1. 
Tindakan kekerasan yang paling tragis yang dilakukan al-Mutawakkil adalah dengan mengadakan control secara intensif dan menindas para sarjana Mu'tazilah. Banyak di antara mereka yang dijatuhi hukuman mati dan sebagiannya dipenjarakan. Selain itu, al-Mutawakkil juga bersikap keras terhadap aliran Syi'ah dan terhadap non Muslim. ${ }^{14}$ Perlakuan al-Mutawakkil terhadap aliran Syj'ah sangat ironis. Makam Husain di Karbala dan bangunan-bangunan peribadatan di sekitarnya dihancurkan dan diratakan dengan tanah serta melarang kaum Syi'ah mengunjungi tempat ini lagi. ${ }^{15}$

Sebagai akibat dari kecenderungannya pada aliran Sunni, al-Mutawakkil juga menghukum orang yang menghina nama baikAbu Bakar, Umar, Aisyah, dan Hafsah. Dan seperti halnya kebenciannya terhadap aliran Mu'tazilah, masyarakat dilarang mengatakan bahwa al-Qur'an itu makhluk yang menjadi bahan pembicaraan seharihari pada masa pemerintahan al-Ma'mun, al-Mu'tasim, dan al-Watsiq. ${ }^{16}$

Wilayah kekerasan dalam islam, sepanjang sejarahnya semakin meluas, dari konflik politik, teologi, ideologi, sampai ke konflik antar kelompok Islam. Belakangan juga muncul bentuk kekerasan dengan mengatasnamakan gerakan puritanisme. Aliran Wahabi, yang merupakan kelanjutan dari aliran Salaf, yang berpangkal pada pikiran-pikiran Ahmad bin Hambal dan kemudian direkonstruksi oleh Ibnu Taimiyah, menerapkan dengan lebih luas arti bid'ah, sebagaj akibat dari keadaan masyarakat Saudi Arabia yang penuh dengan aneka bid'ah, baik yang terjadi pada musim upacara agama ataupun bukan. ${ }^{17}$

Kalau Ibnu Taimiyah, sebagai pembangun aliran Salaf, menanamkan pahampahamnya dengan cara menulis buku-buku dan mengadakan pertukaran pemikiran dan perdebatan, maka aliran Wahabiyah dalam menyiarkan ajaran-ajarannya memakai kekerasan dan memandang orang yang tidak mengikuti ajaran-ajarannya sebagai ahli bid'ah yang harus diperangi sesuai dengan prinsip amar ma'ruf nahi munkar. ${ }^{18}$

Untuk melaksanakan maksud tersebut, Muhammad Abd Wahab, ideolog aliran ini, menjalin kerja sama dengan pangeran Muhammad bin Saud, yang telah memeluk ajaran-ajarannya dan yang telah mengawini anaknya. Sejak saat itu, kekuatan senjatalah yang digunakan oleh aliran Wahabiyah dalam menyiarkan ajaran-ajarannya.

Tindakan kekerasan yang mula-mula dilakukannya adalah membongkar kuburankuburan yang dianggap menjadi tempat pemujaan, lalu diratakannya dengan tanah. Bahkan masjid-masjid pun turut dibongkar di mana diketahui bahwa di samping masjid tersebut terdapat kuburan. Di samping mereka membongkar kuburan wali-wali atau orang-orang saleh biasa, mereka juga memusnahkan tempat-tempat bersejarah, seperti tempat kelahiran Nabi Muhammad,

14 Lihat, S.F. Mahmud, The Strory of islam, (London: Oxford University Press, 1960), p. 102.

${ }^{15}$ Hasan Ibrahim Hasan, Tarikh al-Islam, (Kairo: Maktabah al-Nahdlah al-Mishriyah, 1979), p. 5.

${ }^{16}$ ibid., p. 4.

17 A. Hanafi, Pengantar Theology Islam, (Jakarta: Pustaka al-Husna, 1980), p. 150. Hal-hal yang dipandang bid'ah oleh mereka dan harus diberantas di antaranya jalah: berkumpul bersamasama dalam mau'idan, orang. wanita mengiring jenazah, mengadakan halaqah zikir, bahkan mereka merampas buku-buku tawassulat seperti Dailatul Khairat dan sebagainya. Bahkan kebiasaan sehari-hari juga dikategorikan bid'ah, seperti merokok, minum kopi, memakai pakaian sutera bagi orang laki-laki, bergambar:(foto), dan memakai cincin.

18 /bid., p. 151. 
Abu Bakar, dan Ali di Makkah: Kemudian di Madinah, kuburan sahabat-sahabat Nabi juga diratakan dengan tanah dan cukup diberi tanda-tanda. Sedangkan terhadap kuburan Nabi, mereka hanya menghilangkan hiasanhiasan yang ada padanya dan melarang penggantian selubungnya yang baru..$^{19}$

Berbagai peristiwa kekerasan dalam perjalanan sejarah umat Islam ini menunjukkan bahwa Islam sebagai agama yang mengedepankan perdamaian, kemanusiaan, dan keharmonian hidup, dalam realitas historisitasnya telah bercampur dengan tindakan-tindakan kekerasan yang dilakukan oleh orang atau kelompok tertentu yang pada dasarnya tidak sesuai dengan prinsip-prinsip universal Islam. Hal ini karena adanya pemahaman atas teks keagamaan (al-Qur'an dan Hadis) yang cenderung dipahami sebagai aksi dan pembenaran atas tindakan kekerasan demi melawan ketidakadilan, penindasan, dan kezhaliman.

\section{Islam, Jihad, dan Munculnya Kelompok-kelompok Militan}

Salah satu konsep "aksi" dalam Islam yang terpenting, yang sering dijadikan dasar pembenaran untuk melakukan tindakan kekerasan oleh orang atau kelompok Muslim tertentu adalah konsep "jihad".

Secara umum jihad dapat diartikan sebagai "perang suci". Namun ada beberapa orang Islam menganggapnya sebagai rukun Islam yang keenam. Di antara aliran Islam, kaum Khawarij menggunakan jihad untuk memaksakan pendapat mereka pada sebagian komunitas Muslim demi idealisme transendental. Mereka menekankan bahwa karena Nabi menghabiskan hampir sepanjang hidupnya dengan peperangan, negara Islam harus diorganisir untuk perang dan orang-orang kafir harus dipaksa masuk islam, jika menolak maka ia akan menjadi sasaran pedang, padahal kitab sucial-Qur'an menyatakan "Tidak boleh ada paksaan untuk (masuk) agama (Islam)" (2:256). Lalu apa arti jihad ?, al-Qur'an menyatakan, "Dan perangilah di jalan Allah orang-orang yang memerangi kamu, tetapi janganlah kamu melampaui batas, sesungguhnya Allah tidak menyukai orang-orang yang melampaui batas" (2:190). Dan juga dikatakan, "Dan perangilah mereka itu sehingga tidak ada fitnah lagi, sehingga agama itu hanya untuk Allah belaka. Jjka mereka berhenti (dari memusuhi kamu), maka tidak ada permusuhan (lagi), kecuali terhadap orangorang yang zalim" (2: 193). Berjuang demi Allah sama dengan bejuang demi keadilan. ${ }^{20}$

Jihad, dengan demikian, dimaknai sebagai bentuk penentangan terhadap penindasan, despotisme, dan ketidakadilan di manapun dan kepada siapapun. Dalam pengertian yang sangat luas, jhad bisa berarti berjuang mengenyahkan kejahatan dalam umat (komunitas Musiim), atau suatu perjuangan untuk memurnikan porsi kemanusiaan dengan menerima bimbingan spiritual. Pendeknya, jihad adalah perintah Allah Yang Maha Kuasa dan tradisi Rasulullah yang menuntut suatu uji diri yang terus menerus sehubungan dengan daya kita untuk melawan tirani dan penindasan, suatu pengaturan diri, alat untuk mencapai perdamaian dan menerima tanggung jawab moral. Jihad menempatkan perang dan kekerasan dalam wilayah moral. Tujuan akhirnya adalah mengakhiri "kekerasan struktural". Namun demikian, alat itu tidak terpisah dari pertimbangan moral. Misalnya, al-Qur'an dan Sunnah melarang kaum Muslim untuk membunuh orang tua yang jompo, bayi atau kaum hawa; dilarang mengambil
19 Ibid., p. 152.
${ }^{20}$ Chaiwat, Bulan Sabit ..., p. 214. 
barang rampasan, tetapi kumpulkan barang rampasan, berbuat baik dan bertindak lurus karena Allah mencintai orang-orang yang berbuat baik.21

Bermula dari pemahaman tentang jihad dalam Islam ini, telah banyak lahir jama'ah atau organisasi yang mengatasnamakan Islam dengan jihad sebagai orientasinya, yang bertujuan mendirikan negara Islam. Organisasi militan Islam seperti Jama'ah alTakfir wa al-Hijrah, Tanzhim al-Jihad, dan al-Jama'ah al-Islamiyah-untuk menyebut sebagiannya - adalah representasi dari oraganisasi militan ini. Ketiga jama'ah ini lahir dari rahim gerakan dakwah al-lkhwan al-Muslimun, yang didirikan oleh Hasan alBanna, yang sejak tahun 1940-an sangat diperhitungkan eksistensinya dalam peta politik Mesir dan juga sempat menggegerkan Dunia, khususnya di Timur Tengah. Selain dari al-Banna, ketiga jama'ah tersebut juga menjadi representasi dari pemikiran Sayyid Qutb.

Jama'ah al-Takfir wa al-Hijrah dipimpin oleh SyukriAhmad Musthafa, yang runutan geneologisnya melanjutkan pemikiran Qutbism Ali Abduh ismail dengan organisasi Jama'ah al-Muslimin yang diprakarsainya. Syukri dan Ismail, keduanya merupakan veteran al-Ikhwan yang sering berinteraksi dalam penjara semasa-rezim Nasser. Jama'āh ini mengklaim yang paling berhak untuk menyuarakan dan memperjuangkan Islam. Menurut mereka sebuah perjuangan untuk memenangkan Islam niscaya melalui tiga tahapan: pertama, dimulai dengan berdakwah secara terang-terangan dengan tujuan li i'la'i kalimatillah. Dalam tahap ini, mereka sabar dalam menerima tekanan, cercaan, dan hinaan, sebagaimana pernah dialami Rasululiah di awal dakwahnya. Dengan kesabaran dan ketabahan, pada saatnya nanti mereka yakin akan mendapat dukungan yang kuat dari orang-orang yang betul-betul ingin berjuang menegakkan Islam. Dari tahap ini, nantinya akan terlihat siapa yang beriman dan siapa yang münafik, siapa yang berada dalam kebenaran dan siapa yang berada dalam kesesatan.22

Kedua, tahap al-Sirah (tahap pertanungan untuk menyucikan diri). Pada tahap ini mereka melakukan uzlah atau mengasingkan diri dalam rangka berhijrah menjauhi pengaruh masyarakat jahiliyah. ${ }^{23}$ Setelah jiwa dan mental mereka suci, pada saatnya siap terjun kembali untuk memperbajki masyarakat jahiliyah. Ketiga, tahap kembali ke masyarakat. Mereka akan bergaul di tengahtengah masyarakat jahiliyah dan merombak tatanan-tananannya lalu menggantikannya dengan tatanan-tatanan Islam. Mereka akan menjadi jundullah (tentara Allah) untuk melibas habis jundu al-syaithan yang
21 Lihat, Ibid., p. 214-215.
22 Lihat, A. Yani Anshori, Ideologi dari Penjara: Dari Qutbism Menuju al-Qa'idah. Makalah disampaikan dalam "Moslem Scholars Congress, Reading of The Religious Texts and The Roots of Fundamentalism", di Hotel Saphir Yogyakarta, 13 Juni 2004, p. 18.

${ }^{23}$ Menurüt Sayyid Qutb, dunia sekarang berada dalam kondisi jahiliyah. Kejahiliyahan ini dikarenakan kondisi dunia yang menentang kedaulatan Tuhan (al-hakimiyah lillah). Sekarang umat manusia berada dalam kondisi jahiliyah seperti sebelum Islam ada, atau bahkan lebih buruk lagi. Semua yang nyata tampak serba jahiliyah; pemikiran, kebiasaan, tradisi, budaya, pemerintahan, konstituși dan perundang-undangannya tidak mau tunduk kepada al-hakimiyah lillah seperti yang ditegaskan dalam al-Qur'an dan Sunnah, termasuk segala sesuatu yang tampaknya Islam tetapi sebenarnya produk Barat, semuanya adalah produk jahiliyah jajdidah. Lihat, Sayyid Qutb, Ma'alim fi al-Thariq: (Kairo: Dar al-Syuruq, 1982), p. 20-21. 
menjadi pendukung utama pemerintahan tiràni. ${ }^{24}$.

Jama'ah ini berusaha merangkul keanggotaannya dari orang-orang militer sebanyak mungkin yang berfungsi sebagai garda operasi dan melatih anggota-anggota jama'ah dalam strategi tempur dan menggunakan senjata. Orang-orang militer ini diharapkan mengambil senjata di unitunit militer mereka. Sementara itu, poros aksi ditujukan untuk mendirikan negara Islam. Jama'ah ini berprinsip bahwa satusatunya cara untuk mendirikan negara Islam adalah mengikuti dan menteladani ketentuan-ketentuan dan pengalaman $\mathrm{Nabi}$ Muhammad dalam mendirikan Negara Islam Madinah. Oleh karena itu, hijrah harus dilakukan sebagai tahap permulaan, sehingga selama para mukmin masih berada di tengah-tengah para kafir jahiliyah, maka keruntuhan masyarakat jahiliyah dan pemerintahannya yang kafir tidak akan terjadi. ${ }^{25}$

Sementara itu, jama'ah Tanzhim alJihad, yang kelahirannya tidak terlepas dari ketokohan Muhammad Abdussalam Faraj, yang merupakan ideolog bagi jama'ahnya. Jama'ah ini mempunyai tujuan mengadakan revolusi jihad untuk menentang kejahiliyahan, zionisme Yahudi dan Kristen demi tegaknya negara Islam. Jama'ah ini menyerukan propaganda bahwa untuk membebaskan tanah-tanah suci Isiam dan juga membebaskan negeri-negeri Muslim dari kekangan Zionis dan imperialis seyogyanya terlebih dahuju membebaskan negerinya sendiri dari pemerintahan orangorang kafir. Penguasa-penguasa kafir ini menjadi pendukung utama para zionis dan imperialis. Imperialisme merupakan musuh dalam target jangka panjang, sedangkan penguasa kafir merupakan. musuh dalam target jangka dekat. Perang melawan para kuffar yang mengendalikan pemerintahan lokal merupakan sasaran pertama sebelum beralih ke sasaran-sasaran berikutnya. Negara Islam tidak akan terwujud kecuali melalui perang. Jama'ah ini meyakini bahwa hanya melalui revolusi jihad, perjuangan untuk mendirikan negara-Islam akan tercapai, demikian juga perjuangan untuk meluruskan penguasa dari penyimpanganpenyimpangannya terhadap syariah Islam. ${ }^{26}$

Keberhasilan terbesar dari aksi jihad jama'ah ini adalah kesuksesannya dalam merencanakan pembunuhan terhadap

${ }^{24}$ A. Yani Anshori, Ideologi dari Penjara.., p. 18-19. Bagi mereka, strategi gerakan Islam terbagi menjadi dua poros utama, poros ideologi dan poros aksi. Poros ideologi yaitu dengan melakukan: 1) Pendekatan islam; yaitu Islam akan mengalami pencerahan yang digelorakan para mujahidin dengan mengumandangkan jihad sambil menghunus pedang. 2) Hijrah, yang ditujukan untuk menyucikan diri dari pengaruh masyarakat jahiliyah, yang dimulai dengan membentuk unit-unit masyarakat islam dengan target hijrah ke gunung-gunung atau goa-goa. 3) Qif wa Tabayyan. Konsep ini menolak doktrin bahwa dengan memenuhi lima rukun Islam, seseorang dapat disebut sebagai Muslim yang sempurna. Bagi mereka kesempurnaan seorang Muslim tidak hanya dengan memenuhi lima rukun islam, tetapi juga harus melaksanakan segala perintah Allah dan menjauhi segala laranganNya. Seorang-MusIim yang melanggar perintah Aliah dan melaksanakan laranganNya dianggap telah kafir. 4) al-Qur'an dan Sunnah adalah satusatunya hokum dan perundang-undangan. Sedangkan poros aksi diimplementasikan dengan: 1) Menciptakan struktur keorganisasian bagi gerakan. 2) Menyewa rumahrumah untuk digunakan sebagai kantor-kantor gerakan bawah tanah. 3) Berhijrah ke goa-goa dan pegunungan untuk menerapkan ideologi dan penyucian jiwa. 4) Merekrut orang-orang militer.

$$
\begin{aligned}
& { }^{25} \text { Ibid., p. } 20 . \\
& { }^{26} \text { Lihat, Ibid., p. } 21 .
\end{aligned}
$$


presiden Mesir, Anwar Sadat, yang diberondong peluru oleh team letnan Khalid islambuli. Pembunuhan terhadap Sadat ini juga melibatkan tokoh al-Jama'ah al-' Islamiyah, Umar Abdurrahman, yang dituduh sebagai figur spiritual Tanzhim al-Jihad yang menfatwakan halalnya pembunuhan terhadap Sadat. ${ }^{27}$

Kemudian al-Jamia'ah. al-Islamiyah, yang berdiri tahun 1973 di Minya, Asyut, merupakan organisasi Islam militant di Mesir. Dr. Umar Abdurrahman, pemrakarsa jama'ah ini, dituduh sebagai ideolog utama al-Jama'ah al-Islamiyah yang melakukan aksi kekerasan, perampokan toko-toko Kristen Koptik dan pembunuhan terhadap Rafaat Mahgoub, juru bicara Parlemen Mesir. Di samping-itu, dituduh sebagai pemberi fatwa dalam aksi penyerangan dan tindak kekerasan di berbagai Negara di Ásia dan Afrika. Tahun 1993, ia menjadi Imam sebuah Masjid di New Jersey Amerika Serikat. Sampai akhimya Dr.Umar ditangkap karena terbukti terlibat dalam aksi bombing WTC oleh Ramzy Yousef dan kawankawannya dari al-Jama'ah al-Islamiyah. ${ }^{28}$

Menurut Umar, suatu negara yang kebijakan-kebijakan pemerintahannya tidak sesuai dengan aturan Allah dalam syariạh Islam, maka negara tersebut tidak dianggap sebagai negara orang Islam, meskipun para penyelenggara negara dan semua rakyatnya melaksanakan shalat, zakat, puasa, dan haji. Apa lagi negara tersebut mengikuti faham liberalisme dan sistem demokrasi Barat, karena sudah tentu merupakan negara kafir. Umar menolak sistem demokrasi, liberalisme, dan semua faham politik yang memberikan' otoritas pembuatan aturan-aturan yuridis kepada masyarakat karena hal itu merupakan sebuah bentuk kejahiliyahan. Sebaliknya, sistem pemerintahan yang mampu mengemban tugas alhakimiyah al-ilahiyah adalah sistem al-
Khilafah al-Islamiyah, di mana pemimpin mengikatkan dirinya pada aturan din al-sslam dengan menerapkan syariah Islam dalam semua sisi kehidupan. ${ }^{29}$

al-Jama'ah al-Islamiyah menentang adanya partai-partai politik. Dan menurutnya, hanya ada dua golongan besar saja, yaitu Hizbullah dan Hizb al-Syaithan. Golongan Hizbullah adalah kelompok al-Jama'ah alIslamiyah, sedangkan golongan Hizb alSyaithan adalah kelompok-kelompok selain kelompoknya. Jihad menurut mereka adalah jihad akbar, suatu panggilan berjuang urituk menegakkan penerapan syariah Islam, mensosialisasikan konsep al-Jama'ah alIslamiyah, memobilisasi para mujahid militan, mempersenjatai masyarakat dengan memberi target-target sasaran, melatih gerak fisik, serta menegakkan kewajiban amarma'ruf nahi munkar. ${ }^{30}$ :

Mencermati munculnya berbagai kelompok militan dalam Islam ini, dapat dilihat bahwa selain istilah jihad yang sering dimaknai ke wilayah aksi, istilah amar ma'ruf nahi munkar juga cenderung dipahiami sebagai doktrin dan dasar pembenaran untuk melakukan tindakan-tindakan kekeràsan. Selain itu, ada istilah lain yang cenderung dipahami sebagai suatu doktrin, keyakinan, atau sikap yang mengarah kepada munculnya gerakan fundamentalisme Islam, yaitu doktrin Islam Kaffah.

Kalangan fundamentalisme Islam menjadikan doktrin Islam Kaffah ini sebagai dasar untuk berperilaku. Ayat al-Qur'an yang dijadikan pijakannya adalah ayat "Yâ aiyuha-l-ladzîna âmanû udkhulu fi-s-silmi kâffah..." (Hai orang-ọrang.yang beriman, masuklah ke dalam "Islam" seluruhnya...).
27 Ibid.
${ }^{2 B}$ /bid., p. 22-23.
${ }^{29}$ Lihat, Ibid., p. 23-24.
${ }^{30}$ Ibid., p. 24. 
Kata kaffah (keseluruhan) di sini dipahami oleh Sayyid Qutb agar umat Islam wajib mengikuti al-manhaj al-rabbani, yaitu sistem kehidupan yang diajarkan Tuhan dengan mendasarkan pada aqidah, sehingga membuat damai kehidupan pribadi dan menjadi satu-satunya ikatan sosial yang mampu menyatukan masyarakat dengan tanpa membedakan ras dan daerah, bahasa dan warna kulit, dan seluruh ikatan artifisial lain yang tidak berhubungan dengan substansi manusia. Dengan kata lain umat Islam wajib mengikuti manhaj ini secara total dalam seluruh aspek kehidupan, baik kehidupan pribadi maupun sosial. Dalam kehidupan pribadi, umat Islam harus menganut sistem kepercayaan dan peribadatan Islam. Sedangkan dalam kehidupan sosial, mereka harus mengikuti sistem-sistem Islam dalam pergaulan, ekonomi, politik, dan lain-lain. Konsekuensi dari pemaham ini adalah bahwa orang yang tidak masuk Islam secara total, tidak menyerahkan dirinya secara total dan mumi tunduk kepada Allah dan syariat-Nya, maka ia berada di jalan syetan atau berjalan mengikuti langkah-langkah syetan. ${ }^{31}$

Pemahaman seperti ini cenderung bersifat konfrontatif, melawankan Islam dengan jalan bukan Islam, jalan syetan. Benih-benih pemikiran fundamentalisme ada dalam penafsiran ayat ini hanya oleh penafsiran segelintir orang yang bersikap militan. Fundamentalisme yang semula berawal dari pemikiran atau penafsiran ayat al-Qur'an, kemudian berkembang menjadi aksi atau gerakan-gerakan yang acapkali berbentuk kekerasan dengan mengatasnamakan pembelaan atas agama Islam.

\section{Penutup}

Islam sebagai "agama kekerasan" bisa jadi hanya sekedar mitos, karena ajaran universal Islam mengajarkan perdamaian, keharmonian, toleransi, dan kasih-sayang. Namun; sebagai realitas sejarah harus diakui bahwa dàlam perjalanan sejarah umat Islam telah muncul bentuk-bentuk kekerasan yang dilakukan oleh orang atau kelompok tertentu dengan mengatasnamakan agama Islam. Bermula dari skriptualis, dari al-Qur'an dan Sunnah, dipahami dan ditafsirkan secara sepihak, melahirkan aqidah dan syarjah, lalu melahirkan sikap dan perilaku hidup seorang Muslim. Dan karena model penafsirannya cenderung diarahkan ke wilayah aksi dengan mengkonfrontasikan keadaan dan perkembangan masyarakat dunia modern yang "tidak islami" dari berbagai aspeknya; politik, sosial, budaya, ekonomi, dan sebagainya, maka muncullah kelompokkelompok militan Islam yang melawan kejahiliyahan, ketidakadilan, penindasan, dan kesesatan ajaran, ideologi, atau bentuk pemerintahan, yang tidak hanya ditujukan kepada kelompok lain tetapi juga kepada sesama kelompok Muslim.

Sebagaimana telah diuraikan sebelumnya, dalam perjalanan sejarah umat Islam tidak bisa dilepaskan dengan kekerasan. Sejarah mencatat berbagai kekerasan yang dilakukan oleh orang-orang Musiim dalam perebutan kekuasaan (dinasti); muncul kelompok militan fundamentalis Khawarij yang melakukan kekerasan dan pembunuhan terhadap kelompok yang tidak sepaham denganya. Mu'tazilah yang diklaim sebagai aliran rasional, ketika menjadi sebuah ideologi juga sempat ternodal dengan tindakan kekerasannya dalam peristiwa mihnah. Kelompok Sunni kemudian berbalik melakukan kekerasan terhadap kelompok

${ }^{31}$ Lihat, Sayyid Qutb, Fi Dlilal al-Islam, (Beirut: Dar al-'Arabiyah, t.t.), p. 130-133. 
Mu'tazilah dan Syi'ah. Belakangn juga muncul aliran Salaf yang melakukan kekerasan dengan dalih puritanisme atau pemberantasan bid'ah yang dilakukan oleh aliran Wahabiyah.

Perkembangan selanjutnya muncul kelompok-kelompok militan Islam yang berorientasi kepäda aksi. Jihad, amarma'ruf nahi munkar, Islam kaffah, syariah Islam, dan negara Islam adalah konsep-konsep dan sekaligus doktrin yang banyak diusung ke permukaan. Dalam hal ini, bisa disebut kelompok-kelompok militan Islam seperti, Jama'ah al-Takfirwa al-Hijrah, Tanzhim alJihad, dan al-Jama'ah al-Islamiyah.

Berkembangnya aksi teror, konfik antar agama atau kelompok seagama, dan konfrontasi kelompok keagamaan Islam tertentu dengan pemerintah di Indonesia, pada dasamya bisa dilacak dari akar sejarah "kekerasan" dalam islam sebagaimana yang telah diuraikan di atas, baik dalam kesamaan bentuk teologi, ideologi, atau paham-paham pemikiran/penafsiran-nya, atau juga terlibat langsung dengan kelompok-kelompok militan Islam di atas.

\section{Daftar Pustaka}

Anshori, Yani, Ideologi dari Penjara: Dari Qutbism Menuju al-Qa'idah. Makalah disampaikan dalam "Moslem Scholars Congress, Reading of The Religious Texts and The Roots of Fundamentalism", di Hotel Saphir Yogyakarta, 13 Juni 2004.

Amin, Ahmad, 1975. Fajr al-Is/am, Kairo: Maktabah al-Nahdlah al-Mishriyah.

a!-Dzahabi, Muhammad Husain, 1962. alTafsir dan al-Mufassirun, Kairo: Dar al-Kutub al-Haditsah.
Hasan, Hasan Ibrahim, Tarikh al-Islam, Kairo: Maktabah al-Nahdlah alMishriyah, 1979.

$\therefore=$

Hanafi, A.1980, Pengantar Theology Islam, Jakarta: Pustaka al-Husna.:

Madjid, Nurcholish, 1995. Islam, Doktrin dan Peradaban, Jakarta: Yayasan Wakaf Paramadina.

Machasin, Fundamentalisme dan Terorisme, Makalah disampaikan dalam "Moslem Scholars Congress, Reading of The Religious Texts and The Roots of Fundamentalism", di Hotel Saphir Yogyakarta, 13 Juni 2004.

Mahmud, S.F.1960, The Story of Islam, London: Oxford University Press.

Mudmarn, Seni,1993. "Negara, Kekerasan dan Bahasa: Tinjauan atas Sejumlah Hasil Studi mengenai Kaum Muslim Muangthai" dalam Saiful Muzani, (Ed.), Pembangunan dan Kebangkitan Islam di Asia Tenggara, Jakarta: LP 3 ES.

Nasution, Harun, 1983. Teologi Islam, Jakarta: UI Press.

Quthb, Sayyid,1982. Ma'alim fi al-Thariq, Kairo: Dar al-Syuruq.

Fi Dlilal al-Jslam, Beirut: Dar al'Arabiyah, t.t.

Salmi, Jamil,2005. Violence and Democratic Society: Hooliganisme dan Masyarakat Demokrasi, Terj. Slamet Raharjo, Yogyakarta: Pilar Humania. 
Topik: Budaya Kekerasan

Satha-Anand, Chaiwat dan Qader Muhaideen,1993. "Bulan SabitAnti-Kekerasan: Refleksi atas Perjuangan Kaum Muslim Muangthal" dalam Saiful Muzani, (Ed.), Pembangunan dan Kebangkitan islam di Asia Tenggara, Jakarta: LP 3 ES.

Watt, W. Montgomery, 1990. Kejayaan isOrientalis, Terj. Hartono Hadikusumo, Yogyakarta: Tiara Wacana.

Harian Pagi BERNAS, Selasa, 2 Mei 2006. Jawa Pos, Rabu, 11 Januari 2006.

Harian Seputar Indonesia, Kamis, 5 Januari 2006. 